\title{
Sustainability in urban transport plans. Case study: Monorail in a hillside area in Medellín
}

\author{
Juan Pineda-Jaramillo, M.Sc. \\ Ph.D. student, Universitat Politècnica de València, Spain.
}

\begin{abstract}
One of the most important concepts today is the incorporation of sustainability in urban transport plans. This paper presents the importance that sustainable urban transport plans must have on mobility policy in cities. It also shows the factors that make a transportation mode like urban railway be sustainable. Finally, the Monorail project in the Metropolitan Green Belt (MedellínColombia) is presented, showing its implication on the mobility in this low-income region and its integration with urban and regional plans.
\end{abstract}

KEYWORDS: Sustainable transport systems, Monorail, Environment, Economy, Social equity.

\section{INTRODUCTION}

The Commission's Thematic Strategy on the urban environment (European Commission, 2005) adopted in 2006 describes environmental challenges and problems faced by many cities, like poor air quality, traffic volumes and congestion, high levels of ambient noise, high level of greenhouse gas emissions, social exclusion and urban sprawl. It is a fact that these are serious pressures because they have major effects on the environment, social equity and economy of conurbations.

The thematic strategy proposed that urban mobility contributes significantly to these problems, and for this reason, it is highly recommended the development and implementation of sustainable urban transport plans, where the European Union adopted it in 2006 (Council of the European Union, 2006).

The urban monorail is an ideal mode of transportation adaptable to intermediate distances and capable of satisfying moderate transportation demands. The principal advantages of the monorail are energy-efficiency, significantly reduced emissions per person and a great ability to suit into the conditions of slope.

This paper reviews a case study of transport development in a particular place in Medellín (Colombia), including social equity, environmental and economic aspects, through the implementation of an electric monorail.

\section{LITERATURE REVIEW}

The Rio+20 Summit held in 2012 renewed the global commitment to sustainable development and promoted an economically, socially and environmentally sustainable future. It also recognized that transport and mobility are central to sustainable development. It supported the development of sustainable transport systems, including energy efficient multi-modal transport systems, public mass transportation systems, non-motorized mobility, modal-shift, clean fuels and vehicles, road safety, and the needs of landlocked and transit developing countries need to 
be taken into account while establishing sustainable transit transport systems (United Nations, 2012).

McKenzie identifies in his work (McKenzie, 2004) several attempts to define social sustainability and concludes it generally to be, "a positive condition within communities, and a process within communities that can achieve that condition". This definition is supplemented with a list of corresponding principles, including: Equity of access to key services, equity between generations, a system of relations valuing disparate cultures, political participation of citizens, a sense of community ownership, a system of transmitting awareness of social sustainability, among others.

A sustainable economy depends upon a sustainable flow of material, energy, and environmental resources. Without it, economic systems will fail (Morelli, 2011).

The environment is related to respect for human habitat and other forms of life, so that sustainable transport in the environmental area involves the conservation and maximum limitation of irreversible damage caused by infrastructure and activities carried out in this period of construction, operation and maintenance. Moreover, the economic value is the variable of interest in society and one of the most influential in selecting the transportation mode to be used, and therefore, the studies of economic viability of a transportation mode examines how transportation costs can be reduced and confront monetary expenditures caused by congestion (UITP - Advancing Public Transport, 2002).

Guarantee that each impact executions generated by the man has sustainable development, has been one of the most controversial dilemmas of international debate in recent decades, especially when the background of the Project generates irreparable changes in environmental and social field. For this reason, it has created different standards based on principles such as the right to full and productive life with nature, citizen participation, the sovereign right of states to exploit their own resources, poverty eradication, the entity or individual who generates pollution will pay for producing, previous prevention and evaluation of environmental impact (Perea Velásquez, 2011). So, from each of these principles, every nation constitutes regulatory entities that have the authority to create rules for the monitoring of natural resources and urban planning.

Below are presented some elements that a sustainable urban transport system must include.

- Integrated land use and urban transportation planning: Urban transportation planning must consider land use planning and growth patterns of cities. Integrated transport master plans should be developed considering future growth and expansion. Short, medium, and long term transportation plan need to be developed and implemented. (United Nations, 2013).

- Use of new technology: Fuel-efficient, electric and hybrid cars that are emerging due to advances in vehicle technology. These can make greater contribution to lessening the problems associated with air pollution and fossil fuel use. (United Nations, 2013).

- Public transportation system: Once the various elements of urban transportation infrastructure are developed based on the integrated urban transportation plan, the public transportation services should be provided to urban population including the marginalized urban poor. There could be various forms of interconnected public transportation such as 
bus, LRT, BRT, subway and metro systems, etc. depending on size and economy of the city. In order to reduce dependency on private transport modes, policies to increase share of public transportation modes are essential. Public transportation should be planned to be safe, secure, reliable, frequent, convenient, affordable, clean, comfortable and efficient (Passenger Transport Executive Group, 2009).

- Energy consumption and emissions: Governments around the world are adopting different strategies to reduce energy consumption and emissions from transport operations. These include the use of alternate fuels, greater use of higher quality and efficient public transportation systems, use of innovative technology and efficient vehicle design, reducing trips or vehicle-kilometer traveled, and several forms of travel demand management (Regmi, 2014).

One of the challenges facing governments is the lack of comprehensive assessment tools to understand first, the level and sources of energy use and emissions in the transport sector; and secondly, the impact of different options on these variables (Barrella \& Amekudzi, 2011).

\section{CASE STUDY: MONORAIL IN THE MEDELLIN METROPOLITAN GREEN BELT}

There is a problem in the region of Valle de Aburrá in relation to the informal occupation of the territory, more precisely on the hillside of the city. It has been proposed to carry out a hillside urbanism because the occupation will persist, for this reason, it is necessary to accept that fact and try to build infrastructure (Medellin como vamos, 2014).

The projection and commitment to create a competitive city, inclusive, equitable and with social sense, promotes the concept of urban development plans, capable of contemplating and fulfill the sustainable development idea. As an example of this objective is the Metropolitan Green belt Project which aims to "consolidate the territory of balanced and equitable manner in the meeting zone between the urban, rural and its area of influence" (EDU; Alcaldía de Medellín, 2013).

This project seeks to build an electrical monorail system, which must meet all the requirements for incorporating sustainability as the focus in making key decisions on issues related to environment, social equity and economy.

The study area represents the communes 1, 3, 8 and 9 of Medellín, with a population of 280000 people with low incomes, which represents near of the $7.5 \%$ of the population of the region of the Valle de Aburrá Fig. 1. 


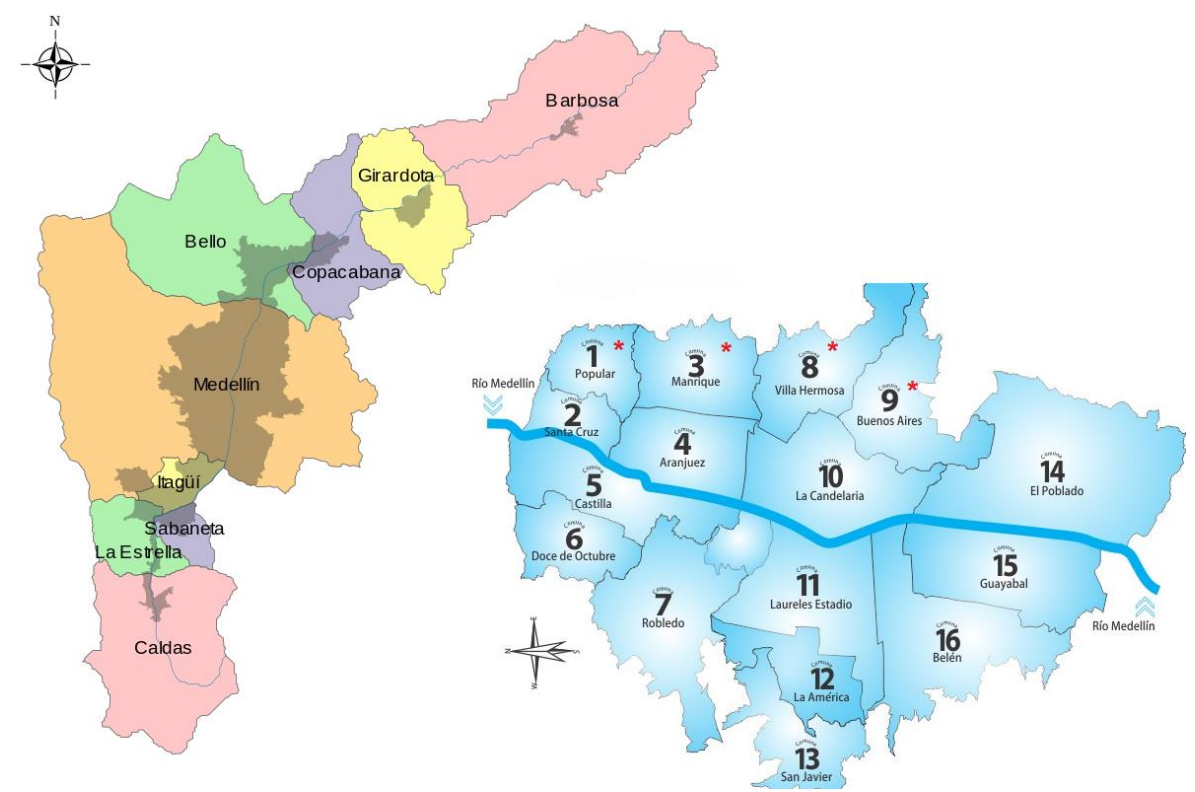

Fig. 1. Medellín within the Valle de Aburrá, and the communes 1, 3, 8 and 9 within Medellín.

Source: Own with information from (Alcaldía de Medellín, 2016).

\subsection{Impact of the project}

Due to the nature of this project, the need to count on with a clean transportation mode is considered essential in order to achieve a balanced integration in the hillside of the city. This project wants to reforest and regain the fauna and flora characteristic of the region to achieve a comprehensive ecological system (Alcaldía de Medellín; Área Metropolitana del Valle de Aburrá; URBAM, 2011).

In the social equity aspect, there is the need to generate a process of social inclusion, in order for people take ownership of it and create culture through time and use (Medellin como vamos, 2014). The public transportation has to serve to the population, including the marginalized urban population.

There are problems related to the viability of the project, because the layout of the route follows a transverse displacement to the usually used by people in the impacted area (Medellin como vamos, 2014). This displacement could encourage a tendency to reject the system and continue the natural travel routes.

Paradoxically another possible problem would be caused by the opposite effect. The growth pattern of cities occurs by the construction of a transportation system, causing the population densification of the areas near to the stations. This could abolish the purpose of sustainable metropolitan green belt due to the mountainous and steep topography of the zone with slopes up to $25 \%$, which may end with landslides and casualties among the population (Alcaldía de Medellín; Área Metropolitana del Valle de Aburrá; URBAM, 2011), (URBAM, 2013).

In the economic aspect, although this transportation mode is considered as one of the most economical (Alcaldía de Medellín; EDU - Empresa de Desarrollo Urbano, 2013), the launch of 
the monorail would represent $70 \%$ of the total budget for the green belt (about 200 million dollars of the year 2013) (Medellín como vamos, 2013).

In the environmental aspect, the electrical monorail is optimum due to energy-efficiency and its reduced emissions per person, being about 20 times less than that produced by a car due to the low consumption, low friction wheel-rail and high demand (ISTAS, 2009).

Other issues of great importance are the ability of this transportation mode to suit into the conditions of slope, be safe, quiet, reliable, its low operational costs and easy construction (EDU; Alcaldía de Medellín, 2013).

\subsection{Incorporation into the urban landscape}

Monorails can be constructed over existing roads, parks, squares, rivers, railroad tracks, etc., exploiting its potential of flexible alignment. Efficient installation is thus ensured while minimizing the need to acquire new land (Japan Monorail Association, 2015). The monorail does not require a large amount of overland area because it is suspended in the air, so it creates spaces available for human activities such as nature trails or bike paths, instead of being occupied by motor vehicles, which is beneficial to the community.

It is necessary to do a proper planning of nearby urban panorama for the construction of the monorail, this is important for the placement of infrastructure, where nature and style of the environment may be preserved.

It is intended that the landscape impact is not modified by the construction of the stations, and instead the urban center be conceived in the terminal and intermediate stations (Martins Goncalves, Da Silva Portugal, \& Nassi, 2009).

In the projects of such magnitude and host, it is inevitable the growth and the settlement of population near of the monorail stations. In addition, since this was designed in a hillside zone with steep slopes, it is expected an informal occupation in the slope, a situation that undermines the concept of sustainability if it is not treated.

The implementation of this system contributes to minimize noise pollution (silent system that generates no more than $75 \mathrm{~dB}$ ) and environmental pollution (using electrical energy instead fossil fuels). Also, the construction and commissioning of the monorail does not affect the environment due to be a fast construction of prefabricated materials that easily adapts to the topography of the area, thus reducing significantly the removal of earth and the whole process that this involves (FILATINA, 2009). (FILATINA, 2009).

\section{CONCLUSIONS}

Tis paper discusses initiatives and policies related to sustainability of transportation systems, explaining that the creation of projects must be strategic, forward-looking and be focused on social and environment integration, which could guide the development within a framework of sustainability, and generate social equity and a balance between man and the environment.

In the environmental field, the transport sector is one of the major direct causes of greenhouse gases and, due to be an alarming trend, a priority is to develop more sustainable transport like the railway, which employs clean energy as electrical energy. 
In the economic field, transport is the central axis of the development of a zone. However, do not forget that one of the benefits associated with transportation modes is to reduce travel times, creating more available time for dedicate to other activities, becoming a key factor in the development of a society.

It is important to Integrate the railway in the urban transport plans to contribute to the solution of social and environmental problems, connecting different locations of the regions in a sustainable and clean way.

\section{REFERENCES}

Alcaldía de Medellín. (2016). Alcaldía de Medellín. Retrieved January 15, 2016, from Alcaldía de Medellín:

https://www.medellin.gov.co/irj/portal/ciudadanos?NavigationTarget=navurl://42eecd3 9c10c1acbfa06e04587c820aa

Alcaldía de Medellín; Área Metropolitana del Valle de Aburrá; URBAM. (2011). BIO 2030, Plan Director Medellín, Valle de Aburrá. Medellín.

Alcaldía de Medellín; EDU - Empresa de Desarrollo Urbano. (2013). Cinturón verde Metropolitano, la máxima expresión del urbanismo cívico - pedagógico. Medellín.

Barrella, E., \& Amekudzi, A. A. (2011). Backcasting for sustainable transportation planning. Transportation Research Record, 29-36.

Council of the European Union. (2006). Renewed EU Sustainable Development Strategy. Brussels.

EDU; Alcaldía de Medellín. (2013). Monorriel: sistema de movilidad limpia. Medellín. European Commission. (2005). EU Policy on the Urban Environment. Brussels.

FILATINA. (2009). Monorrieles para las ciudades: más económico, moderno, masivo y económico que subtes, trenes, taxis y ómnibus. Retrieved from FILATINA: http://filatina.wordpress.com/2009/08/01/monorrieles-para-las-ciudades-maseconomico-moderno-masivo-y-economico-que-subtes-trenes-taxis-y-omnibus/

ISTAS. (2009). Glosario de movilidad sostenible. Barcelona, España: Primera edición.

Japan Monorail Association. (2015). Japan Monorail Association. Retrieved Januray 28, 2016, from Japan Monorail Association Guide: http://www.nihonmonorail.or.jp/pamphlet/313.pdf

Martins Goncalves, J. A., Da Silva Portugal, L., \& Nassi, C. D. (2009). Centrality indicators as an instrument to evaluate the integration of urban equipment in the area of influence of a rail corridor. Transportation Research Part A, 43, 13-25.

McKenzie, S. (2004). Social sustainability: towards some definitions. University of South Australia, Hawke Research Institute, Magill.

Medellín como vamos. (2013). Mesa de trabajo, Retos y oportunidades del cinturón verde Metropolitano. Medellín.

Medellin como vamos. (2014, 04 20). Medellin como vamos. Retrieved from Medellin como vamos: http://www.medellincomovamos.org/editoriales/cinturon-verde-metropolitanoel-buen-dios-esta-en-el-detalle

Morelli, J. (2011). Environmental sustainability: A definition for environmental professional. Journal of Environmental Sustainability, 1, 19-27.

Passenger Transport Executive Group. (2009). The Benefits of Simplified and Integrated Ticketing in Public Transport. Retrieved 12 10, 2013, from Passenger Transport 
Executive Group: http://www.pteg.net/NR/rdonlyres/EACFCEE0-F212-467F-B3422B9B9538DEED/0/integratedticketingreport221009.pdf

Perea Velásquez, F. A. (2011). Legislación básica ambiental. Retrieved Enero 10, 2014, from Colombia aprende: http://www.colombiaaprende.edu.co/html/docentes/1596/articles178898_archivo.doc.

Regmi, M. B. (2014). Moving towards sustainable transport systems in Asia. Transportation Research Board 2014.

UITP - Advancing Public Transport. (2002). Billete al futuro, 3 paradas de la movilidad sostenible. Retrieved Enero 30, 2014, from UITP - Advancing Public Transport: http://www.railway-mobility.org/docs/uitpticket_es.pdf

United Nations. (2012). The future we want.

United Nations. (2013). Forum of Asian Ministers of Transport. Economic and Social Commission for Asia and the Pacific. Bangkok.

URBAM. (2013). Movilidad en la ladera ¿incluir, conectar, hacer ciudad? Universidad EAFIT, Medellín. 